\title{
Extreme Environment - A New Realm of Limnology \\ Kenji KaTO
}

A hot spring is an easily accessible extreme environment which has been regarded as a very minor or at least very specific constituent of limnetic environments. However, a hot spring provides not only a thermal environment but an anoxic condition which partly represent very ancient environment of Earth. More than half of the history of Earth is recognized as having anoxic or very low oxygen concentration conditions with less than $10^{-1} \mathrm{PAL}$ (Present Atmospheric Level). Prokaryotic microbes of Bacteria and Ar. chaea were the form of life throughout this period. Thus, neither paleontlogy nor evolutionary biology have paid much very less attention fo the time of Pre-Cambrian Period. However, when we think of the machinery evolution of organisms and evolution of Earth environment itself, we have to study this period. Life evolved in an ecosystem consisting only of prokaryotic microbes (KATO, 1996). In other words, the pristine ecosystem was constructed with Prokaryotes alone. The number of trophic level was very limited in a pristine ecosystem. The complexity of this ecosystem increased with the evolution of life.

When some geothermal springs in Japan contain significant amounts of hydrogen sulfide with low oxygen concentration of less than $1 \mathrm{ppm}$ and hot water with 50 to $70{ }^{\circ} \mathrm{C}$ is flowing, white turf-like biomat appears. This so-called sulfur-turf was first described by G. MrYoshi a century ago. We found that the major constituent of sulfur-turf is the most deeply branched chemolithotrophic bacteria (YАмамото et al., 1998). What this means was reviewed by Yamamoto as "Hot Spring Biomat as Living Fossil for Studying a Pristine Ecosystem."

We also found viruses in the sulfur-mat complex, and we still obtained some experimental evidence that these viruses/virus-like particle may act as gene transfer agents and population controllers in a pristine ecosystem; reviewed by Chiura as "Viruses could be Promoters of Biodiversity."

A grand scheme of the evolution of the environment as it relates to microbial activity was reviewed by KAWAKAMI as "History of Life and Earth."

Limnetic? What is limnetic on Mars? One of possible extension of these studies is to understand exterme life on Mars. KoIKE reviewed state-of-the art bioscience regarding Mars and what it means in "Possibility of Life and Environment on Mars."

Kenji Kato : Laboratory of Biology, School of Allied Medical Sciences, Shinshu University, 3-1-1 Asahi, Matsumoto, 390-8621 Japan

e-mail : kkatobo@gipac.shinshu-u.ac.jp

(加藤憲二：干 390-8621 松本市旭 3-1-1, 信州大学医療技術短期大学部) 


\title{
Hot Spring Biomat as a Living Fossil for Approach to Pristine Ecosystem
}

\author{
Hiroyuki Yamamoto
}

Microbial mats (biomats) propagate in a wide variety of aquatic environments, including geothermal hot springs and hydrothermal vents. Geothermal and hydrothermal environments harbor many kinds of hyperthermophilic and thermophilic microbes belonging to various phylogenetic positions, e.g., those of oxygenic cyanobacteria and anoxygenic phototrophic bacteria, chemolithotrophic bacteria, chemolithoorganotrophic archaea, and even viruses (virus-like particles; VLP). These microorganisms create biomats with a turf like or a laminate structure. These biomats in thermal habitats have involved a variety of peculiar microbial communities and evolutionary events since the dawn of the prokaryote kingdom.

Phylogenetic evidence based on nucleotide sequences of $16 \mathrm{~S}$ ribosomal RNA gene from existing modern prokaryotes demonstrates that thermophilic bacteria and archaea belong to the oldest group in evolutionary history (Woese, 1987 ; Olsen et al., 1994 ; YамAMOTO et al., 1998). The thermophiles are able to metabolize inorganic matter, e.g., $\mathrm{S}, \mathrm{H}_{2} \mathrm{~S}, \mathrm{Fe}$ (III), and $\mathrm{H}_{2}$, as their energy source (MADIGAN. et al., 1997 ; VARGAS. et al., 1998.). In the early phase of the Earth environment, macromolecular organic substances (sugar and peptide) were rare and even small organic molecules might be valuable building blocks a cellular component. Thus, it is considered likely that the source of the earliest respiring form was inorganic chemicals which existed abundantly in the environment duing Archean Eons ( 3.9 billion years ago) .

Thermophilic chemolithotrophs posses a peculiar sulfur-containing quinone molecule (methionaquinones ; MTKs) in their respiratory electron transport system. The quinone profile of modern prokaryotes approximately agrees with the order of the phylogenetic tree of 16S rRNA (HIRAISHI, et al., 1999). Another distinct physiological property of the thermophiles is a reverse TCA cycle for $\mathrm{CO}_{2}$ fixation (IsHII et al., 1989; IsHII et al., 1997). Some of the chemolithotrophic bacteria may drive the TCA cycle only In a reverse direction.

Fossil evidence of microbial life resembling rod like or filamentous bacteria remains in rocks 3.6 billion years old and younger (Schopf; 1993). It is unknown whether these microfossils were chemolithotrophic or some other type. Stromatolites are fossils fond in microbial mats created mainly by phototrophic bacteria growing during the Proteozoic Eons ( 2 to 3 billion years ago). Older stromatolites probably originated as ancestor of thermophilic anoxygenic phototrophic bacteria (chloroflexus group). After oxygenic phototrophs (cyanobacteria) appeared and generated molecular oxygen on Earth, life took another evolutionary direction leading to the diversity of modern organisms. The time sequences of microbial fossils and geological records partially confirm the $16 \mathrm{~S}$ rRNA molecular phylogeny, and elucidate 
microbial evolutionary history.

The temperature sequence in a hot spring stream creates a diverse microbial flora. The structure of the flora probably agrees with the order of prokaryotes phylogeny. Thermophilic chemolithotrophic bacteria, descendants of the oldest microbes, inhabit the highest temperature areas. A secondary area (ca. $60^{\circ} \mathrm{C}$ ) is the phototrophic world, and anoxygenic. Oxygenic phototrophs grow in the lower temperature. These changes with descending temperature simulate the evolutionary time of Earth's ecosystem, suggesting that the hot spring biomat constituents a "living fossil" which can shed light on the most pristine ecosystem that ever existed on the Earth some 3.8 billion years ago.

Hiraishi, A., T. Umezawa, H. Yamamoto, K. Kato, and Y. Maki. (1999) : Changes in Quinone Profiles of Hot Spring Microbial Mats with a Thermal Gradient. Appl. Environ. Microbiol. 65 : in press.

Ishit, M., Y. Igarashi, and T. Kodama (1989) : Purification and characterization of ATP : citrate lyase from Hydrogenobacter thermophilus TK-6. J. Bacteriol. $171:$ 1788-1792.

Ishi, M., T. Miyake, T. Satoh, H. Sugiyama, Y. Oshima, T. Kodama, and Y. IGARASHI (1997) : Autotrophic carbon dioxide fixation in Acidianus brierleyi. Arch. Microbiol. $166: 368-371$.

Madigan, M. T., J. M. Martinko, and J. Parker (1997) : Brock Biology of microorganisms, eighth edition. Prentice Hall, Inc., Upper Sddle River, NJ.

OLSEN, G. J., C. R. WoEse, and R. OverbeEk (1994) : The winds of evolutionary change : breathing new life into microbiology. J. Bacteriol. 176(1) : 1-6.

SCHOPF, J. V. (1993) : Microfossils of the early Archean apex chart : new evidence of the antiquity of life. Science. $260: 640-646$.

Vargas, M., K. Kashefi, E. L. Blunt-Harris, and D. R. Lovley (1998) : Microbiological evidence for Fe (III) reduction on early Earth. Nature. 395 : 65-67.

WoEsE, C. R. (1987) : Bacterial evolution. Microbiol. Rev. 51(2) : 221-271.

Yamamoto, H., A. Hiraishi, K. Kato, H. X. Chiura, Y. Maki, and A. Shimizu (1998): Phylogenetic evidence for the existence of novel thermophilic bacteria in hot spring sulfur-turf microbial mats in Japan. Appl. Environ. Microbiol. 64(5) : 1680-1687.

Hiroyuki Yамамото : Department of Microbiology, St. Marianna University School of Medicine Sugao 2-16-1, Miyamae, Kawasaki, Kanagawa 2168511, Japan, E-mail : kyama@marianna-u.ac.jp

（山本敬之：テ 216-8511 川崎市宫前区菅生 2-16-1 聖マリアンナ医科大学 微生 物学教室) 


\title{
Viruses Could Be Promoters of Biodiversity
}

\author{
Hiroshi X. CHIURA
}

The major roles postulated for viruses abundantly found in aquatic environments include bacterial population control and gene transfer in situ [BERGH et al., 1989 ; OGUNSTEIn et al., 1990 ; SAYE et al., 1990 ; Miller and SAYLER, 1992 ; RIPP et al., 1994]. The virus genome has a chimerical structure, and respective genes have been incorporated into a part of the virus genome from the host [CAMPBELL, 1988]. Among prokaryotes, a tendency have been observed to make their genome size light in the adaptation process, one extreme being the ultramicrobacteria whose genome size is estimated as one third that of Escherichia coli [Schut et al., 1993]. The co-existence of viruses and bacteria, especially viruses with a lysogenic character, could indicate a coevolutionary partnership designed to supply complementary genetic sources to the bacterial community [LEviN and LENSKI, 1983]. Horizontal gene transfer is important to the evolution and genetic diversity of natural microbial communities, and urgently needs to be understood. However, bacterial cells generally restrict the acceptance of foreign genetic materials through their cell surface [BIRGE, 1994]. A study exists on ubiquitous modes of gene transfer, such as conjugation, plasmidmediated genetic transformation, and virus (phage)-mediated transduction [GAUTHIER and BREITTMAYER, 1990]. Although "trans-kingdom" gene transfer has also been reported [HEINEMAN and SpRAGUE, 1989], the occurrence of gene transfer between different bacterial species and genera in nature has rarely been reported [MAZODIER et al., 1989; SCHAFER et al., 1990].

The spontaneous induction rate for coliphages $\lambda$ and $\mathrm{Mu}$ lysogens under experimental conditions is estimated to be $0.5 \%$ [BRIGE, 1994] and $\sim 0.01 \%$ [LJUNGQUEST and BUKHARI, 1977], while, in an aquatic environment, a small percentage of the bacterial inhabitants have been reported to contain mature virus particles [HENNES and SIMON, 1995]. A large discrepancy therefore exists between the rates measured in natural virus and in experimental conditions. As for lysogens, over $3 / 4$ of the marine microbial population is considered to be infected by viruses [PROcTER et al., 1993]. Further, Salmonella species isolated from hospitals have been recently reported to be lysogenized by more than $90 \%$ with a high frequency of spontaneous induction and generalised transduction [SCHICKLMAIER and SCHMIEGER, 1995]. Therefore, such viruses produced by lysogens could play an important role in biomass control and gene transfer in the natural microbial community.

We have demonstrated that several marine isolates release Virus-Like Particles (VLPs) to the culture broth without artificial induction during prolonged incubation [CHIURA and TAKAGI, 1994; ChIURA et al., 1995; ChIURA, 1997]. Moreover, such VLPs have been shown to have bactericidal effects and a gene-transfer capability towards recipient Escherichia coli, which is not related to their original host at least at the family level [CHIURA and TAKagi, 1994 ; ChiUra et al., 1995 ; ChIURA, 1997]. Such findings suggest that VLPs are not under the same controls as the conventional 
molecular view of virus genetics generally postulates.

The biological activity of VLPs in genetic information exchange was examined. During VLP-mediated gene transfer experiments using Escherichia coli $\mathrm{AB} 1157$ as the recipient, a $93 \sim 60 \%$ death rate of $E$. coli was shown as the efficiency of plating (EOP). Furthermore, the yield of a genetransferred recipient which regenerated amino acid deficiency was obtained at $5.0 \sim 0.1 \pm 0.1 \sim 0.03 \times 10^{-4}$ frequencies. This phenomenon was observed among several marine bacteria, suggesting that physiological functions might be a common feature of certain marine bacteria. Such results, together with electron microscopic observations strongly suggests to us that there exists an interspecific and/or intergeneric natural genetic transfer system.

As mentioned above, a generally high occurrence of transduction in nature mediated by VLPs is predicted, and experimental evidence of this has been reported. We have shown that some marine VLPs are capable of gene transfer to a phylogenetically different strain. Furthermore, we have discovered abundant VLPs derived from the phylogenetically oldest eubacteria (Aquifex-Hydrogenobacter complex) in hot springs. Preliminary evidence of gene transfer in $E$. coli and Bacillus subtilis, which are phylogenetically recent, was obtained by using VLPs. These findings suggest that VLPs in the natural environment can be promoters of biodiversity, and have contributed the evolution of prokaryotes since the early era in the Earth.

\section{REFERENCES}

BørsheIM, K. Y. (1993.) : Native marine bacteriophages. FEMS Microbiol. Ecol. $102: 141-159$.

Børsheim, K. Y., G. Bratbak, and M. Heldal (1990) : Enumeration and biomass estimation of planktonic bacteria and viruses by transmission electron microscopy. Appl. Environ. Microbiol. 56 : 352-356.

Bergh, $\emptyset .$, K. Y. Børsheim, G. Bratbak and M. Heldal (1989) : High abundance of viruses found in aquatic environments. Nature $340: 467-468$.

Birge, E. A. (1994) : Bacterial and bacteriophage genetics - 3rd edn SpringerVerlag, New York.

CAMPBell, A. (1988) : Phage evolution and speciation In : Calender, R. (ed) The bacteriophage. I. Plenum Press New York, N.Y. p. 1-14.

Chiura, H. X. and J. TAKagi (1994): Phage-like particles production and gene transfer by marine bacteria. Bul. Jap. Soc. Microbial. Ecol. 9 : 74-90.

Chiura, H. X., K. Kato and J. Takagi (1995) : Phage-like particles released by a marine bacterium. Wien. Mitteil. 128 : 149-157.

Chiura, H. X. (1997) : Generalized gene transfer by virus-like particles from marine bacteria. Aquat. Microb. Ecol. 13, 74-85.

Gauthier, M. J. and V. A. Breittmayer (1990) : Gene transfer in marine environments. In Bacterial Genetics in Natural Environments. FRY, J. C., and M. J. Day (eds.) Chapman \& Hall. p. 100-110.

Heineman, J..A. and G. F. Sprague Jr. (1989) : Bacterial conjugative plasmids mobilize DNA transfer between bacteria and yeast. Nature $340: 205-209$.

Hennes, K. P. and M. Simon (1995) : Significance of bacteriophages for controlling bacterioplankton growth in a mesotorophic lake. Appl. Environ. Mi 
crobiol. $61: 333-340$.

Levin, B. R. and R. E. Lenski (1983) : Coevolution in bacteria and their viruses and plasmids. In : Futuima, D. J. and Slatkin, M. (eds) Coevolution. Sunderland, Sinauer, Ma. p. 99-127.

LuUngquest, E. and A. I. Bukhari (1977) : State of prophage Mu DNA upon induction. Proc. Natl. Acad. Sci. 74 : 3143-3147.

Mazodier, P., Petrer, R. and C. Thompson (1989) : Intergenic conjugation between Escherichia coli and Streptmyces species. J. Bacteriol. $171: 3583^{-}$ 3585.

Miller, R. V. (1998.) : Bacterial gene swapping in nature. Scientific American, January. 66-71.

Miller, R. V. and G. S. SAyler (1992) : Bacteriophage-host interactions in aquatic system. In Genetic Interactions among Microorganisms in the Natural environment. E. M. H. Wellington and J. D. VAN Elsas (eds.), Pergamon Press, Oxford, p. 176-193.

Ogunseitan, O. A., G. S. Sayler and R. V. Miller (1990) : Dynamic interactions of Pseudomonas aeruginosa and bacteriophages in lake water. Microb. Ecol. $19: 171-185$.

Procter, L. M., A. Okubo and J. A. Fuhrman (1993) : Calibrating estimates of phage-induced mortality in marine bacteria: Ultrastructural studies of marine bacteriophage development from one-step growth experiments. Microb. Ecol. 25 : 161-182.

Ripp, S., O. A. Ogunseitan and R. V. Miller (1994): Transduction of a freshwater microbial community by a new Pseudomonas aeruginosa generalized transducing phage, UT1. Mol. Ecol. $3: 121-126$.

Saye, D. J., O. Ogunseitan, G. S. Sayler and R. V. Miller (1990) : Transduction of a linked chromosomal genes between Pseudomonas aeruginosa during incubation in situ in a freshwater habitat. Appl. Environ. Microbiol. 56 : 140- 145 .

Schafer, A., J. Kalinowski, R. Simon, A. -H. Seep-Feldhus and A. Puhler, (1990) : High-frequency conjugal plasmid transfer from Gram-negative Escherichia coli to various gram-positive coryneform bacteria. J. Bacteriol. $172: 1663-1666$.

Schicklmaier, P. and H. Schmieger (1995) : Frequency of generalized transducing phages in natural isolates of the Salmonella typhimurium complex. Appl. Environ. Microbiol., 61: 1637-1640.

Schut, F., E. J. de Vries, J. C. Gottschal, B. R. Robertson, W. Harder, R. A. PRINS and D. BuTTON (1993) : Isolation of typical marine bacteria by dilution culture: Growth maintenance, and characteristics of isolates under laboratory conditions. Appl. Environ. Microbiol. 59 : 1250-1260.

Hiroshi X. Chiura : Department of Biology, Division of Natural Sciences, International Christian University 3-10-2 Osawa, Mitaka, Tokyo 181-8585, Japan E-mail : chiura@ic.ac.jp

（千浦 博：干 181-8585 三鷹市大沢 3-10-2 国際基督教大学 理学科 生物学教 室) 


\section{History of Life and the Earth}

\section{Shin-ichi KaWAKami}

The origin and evolution of life constitute major events in the history of the Earth. The origin of life, of photosynthesis, of eukaryotes, and the emergence of metazoa are regarded as major events in biological evolution. Recent progress in the study of earth history has revealed that major events in the history of solid earth and earth surface environments were closely associated with the timing of that biological evolution. To understand the geological causes and consequences of major biological events calls for an interdisciplinary approache between the geosciences and biosciences. We briefly discuss some important geological data on the Archean and Proterozoic biospheres. First, the earliest evidence of life comes from the $3.8 \mathrm{Ga}$ Isua supracrustal rocks of West Greenland. Recent carbon isotope measurements of graphites separated from apatite grains by MoJzsIs et al. (1996) ratio showed that these samples suffered a sever fractionation of carbon isotope which was formerly interpreted as reflecting biological carbon fixation. However, it has been pointed out that since inorganic fractionation during thermal metamorphism could also produce the same degree of carbon isotope fractionation, it is still uncertain whether the origin of life can be dated back to $3.8 \mathrm{Ga}$. Recently, TAKANO (1998) discovered apatite-rich thin layers in the banded iron-formations from Isua. It is important to determine whether or not these layers were formed by biological activities at the time of deposition. Second, intensive geological mapping of the North Pole area of Pilbara Block, Western Australia (3.5 Ga) has been completed by the Japanese Decoding Earth Evolution Program led by S. Maruyama. They showed that the greenstone belts in the Pilbara Block have geological structures characteristic of an accretionary complex, and that pillow basalts in association with chert layers and dykes (so-called T-cherts) were formed at the mid-ocean ridge setting. This finding suggests that the oldest stromatolites discovered in the 1980s were not typical stromatolites formed at the intertidal settings but originated from seafloor hydrothermal deposits. They further discovered bacteria-like microfossils within the chert layers covering the pillow basalts. These are the oldest fossils so far discovered. The geological setting suggests that they are remnants of an ancient ecosystem developed at the sites of high-temperature hydrothermal systems. On the other hand, we have examined laminations of Precambrian stromatolites and banded-iron formations, and also reviewed papers on stromatolites/recent microbial mats and banded iron-formations in terms of Precambrian biological activities and paloe-environmental indicators. The oldest Indian manganese deposits associated with banded-iron formation and stromatolites was about $3.0 \mathrm{Ga}$, which suggest that the Archean ocean was stratified in terms of redox state with anoxic deep water underneath oxic shallow water, and that the emergence of cyanobacteria dates at least back to this age. Since both the number of occurrences and the diversity of morphology of stromatolites rapidly increased after about $2.7 \mathrm{Ga}$ ago, and 
large Superior-type banded iron-formations were deposited from about 2.6 to $1.8 \mathrm{Ga}$, these characteristic deposits indicate that the redox states of oceans increased from 2.6 to $1.8 \mathrm{Ga}$. The inferred increase in partial oxygen pressure during the early Proterozoic was supported by the occurrence of red beds and thermodynamic estimations of oxygen pressure using paleosols. The rapid increase in partial oxygen pressure resulted in the evolution of aerobic respiration and the emergence of eukaryotes. Here we propose that the ultimate cause for the oxygen increase was rapid crustal growth triggered by a catastrophic overturn of mantle convection. Furthermore, an increase in partial oxygen pressure may have induced a sudden and rapid evolution of metazoa at the end of the Proterozoic. Although significant environmental changes, including the supercontinental formation and breakup, extensive glaciations, etc, occurred, geological evidence indicative of an increase in oxygen partial pressure at the end of Proterozoic is still elusive.

\section{REFERENCES}

Mojzsis, S. J., G. Arrhenius, K. D. McKeegan, T. M. Harrison, A. P. Nutman, and C. R. L. Fridend (1996) : Evidence for life on Earth before 3,800 million yeas ago. Nature, 384, 55-59.

Takano, M. (1998): Development of a new technology for Decoding Earth Evolution Program, Kagaku, 68, 778-781.

Shin-ichi KawaKami : Faculty of Education, Gifu University, 1-1Yanagito, Gifu, 501-1193 Japan

E-mail : kawa@cc.gifu-u.ac.jp

(川上紳一： ₹ 501-1112 岐阜市柳戸 1-1 岐皁大学教育学部)

\section{Possibility of Life and Environment on Mars}

\section{Junpei KoIKE}

In 1975, the Viking mission to Mars carried experiments specifically designed to search for signs of microbial life on Mars. The results from the Viking landers would suggest that biological activity was not present at the landing sites. However, Viking did provide convincing evidence that liquid water was present on early Mars, and that its atmospheric pressure and temperature were considerably higher than at present. If life did evolve on Mars at some time in the past, is it a forgone conclusion that this life is now extinct? What kind of life might survive in a Martian environment? (MCKAY and STOKER, 1989). Although the present conditions on Mars are not at all favorable to Earth-type life, what kind of terrestrial microbes could live, and for how long can live in such an environment? This question is of fundamental interest.

We have been studying the survivability of some species of terrestrial microorganisms under simulated Martian condition (KoIKE et al., 1995). The environment of Mars was simulated by low temperature, proton irradiation, and vacuum ultraviolet irradiation under gaseous conditions by using a 
special cryostat vehicle. From the result, spores of Bacillus, Aspergillus and Clostridium showed considerably high survivability rates.

Could life on Mars have survived to the present? We think it could. It could be inferred from our experiment that if Earth-type life did evolve on early Mars, it could survive from the primeval early warm period to the present state at the planet's polar caps. Future missions to Mars will confirm this inference.

We have also been studying the issue of a planetary quarantine, that is, the possibility that planets in our solar system might be contaminated by terrestrial microorganisms embedded within the spaceprobes (KoIKE et al. 1996). This problem is not merely an academic one, but fundamental in preventing the contamination of other planets in our solar system. The search for life on Mars should be done, therefore, taking the upmost precautionary measures.

C. P. MCKay and C. R. Stoker (1989) : The early environment and its evolution on Mars ; Implication for life. Rev. of Geophysics, 27, 189-214.

J. Koike, T. Oshima, K. Kobayashi and Y. Kawasaki (1995): Studies in the search for life on Mars. Adv, in Space Research, 15, 211-214.

J. KoIKe, T. Oshima, K. Kobayashi and K. A. KoIKe (1996) : Fundamental studies concerning planetary quarantine in space. Adv. in Space Research, 18, 339344.

Junpei KoIKE : Tokyo Institute of Technology, Faculty of Bioscience and Biotechnology 4259 Nagatsuta, Midori, Yokohama 226-8501, Japan,

E-mail : jkoike@bio.titech.ac.jp

(小池惇平：干 226-8501 横浜市緑区長津田 4259 東京工業大学 生命理工学部) 